\title{
Evaluation of frozen ground conditions along a coastal topographic gradient at Byers Peninsula (Livingston Island, Antarctica) by geophysical and geoecological methods
}

\author{
António Correia $^{\mathrm{a}, *}$, Marc Oliva ${ }^{\mathrm{b}}$, Jesús Ruiz-Fernández ${ }^{\mathrm{c}}$ \\ a Institute of Earth Sciences and Department of Physics, University of Évora, Portugal \\ b Centre for Geographical Studies - IGOT, Universidade de Lisboa, Lisbon, Portugal \\ c Department of Geography, University of Oviedo, Oviedo, Spain
}

\section{A R T I C L E I N F O}

\section{Article history:}

Received 29 February 2016

Received in revised form 3 August 2016

Accepted 4 August 2016

Available online 10 August 2016

\section{Keywords:}

Byers Peninsula

Maritime Antarctica

Geophysical surveying

Electrical resistivity tomography

Geomorphology

Permafrost

\begin{abstract}
A B S T R A C T
Geophysical surveying and geoelectrical methods are effective to study permafrost distribution and conditions in polar environments. Geoelectrical methods are particularly suited to study the spatial distribution of permafrost because of its high electrical resistivity in comparison with that of soil or rock above $0{ }^{\circ} \mathrm{C}$. In the South Shetland Islands permafrost is considered to be discontinuous up to elevations of $20-40 \mathrm{~m}$ a.s.l., changing to continuous at higher altitudes. There are no specific data about the distribution of permafrost in Byers Peninsula, in Livingston Island, which is the largest ice-free area in the South Shetland Islands. With the purpose of better understanding the occurrence of permanent frozen conditions in this area, a geophysical survey using an electrical resistivity tomography (ERT) methodology was conducted during the January 2015 field season, combined with geomorphological and ecological studies. Three overlapping electrical resistivity tomographies of $78 \mathrm{~m}$ each were done along the same profile which ran from the coast to the highest raised beaches. The three electrical resistivity tomographies are combined in an electrical resistivity model which represents the distribution of the electrical resistivity of the ground to depths of about $13 \mathrm{~m}$ along $158 \mathrm{~m}$. Several patches of high electrical resistivity were found, and interpreted as patches of sporadic permafrost. The lower limits of sporadic to discontinuous permafrost in the area are confirmed by the presence of permafrost-related landforms nearby. There is a close correspondence between moss patches and permafrost patches along the geoelectrical transect.
\end{abstract}

(c) 2016 Elsevier B.V. All rights reserved.

\section{Introduction}

Frozen ground conditions exert a key control on geomorphological dynamics in ice-free areas of periglacial environments, which have been broadly defined as those regions with mean annual temperatures ranging from -2 to $3{ }^{\circ} \mathrm{C}$ (French, 2007). However, frozen ground conditions can be permanent (permafrost) or seasonal (seasonal frost). The soil frost regime has large implications on soil, hydrological, biological and geomorphological processes prevailing in cold-climate environments (Oliva et al., 2014).

In some cases, though, it may be difficult to identify the spatial boundary between seasonal frost and permafrost conditions. With the purpose of detecting this limit, increasing number of boreholes and shallow drillings are recently been established for monitoring permafrost and active layer dynamics in mid-latitude mountain regions as

\footnotetext{
* Corresponding author at: Institute of Earth Sciences and Department of Physics, University of Évora, Portugal, Colégio Luis António Verney, Rua Romão Ramalho, 59, 7002-554 Évora, Portugal.

E-mail address: correia@uevora.pt (A. Correia).
}

well as in polar environments (e.g. Harris et al., 2003; Haeberli et al., 2010; Romanovsky et al., 2010). Also, two international programmes (Global Terrestrial Network for Permafrost and Circumpolar Active Layer Monitoring System), led by the International Permafrost Association, have been implemented in order to establish protocols to monitor permafrost and active layer parameters worldwide. In the case of Antarctica, by 2010 there were 73 boreholes and 28 CALM sites (Vieira et al., 2010) although this is clearly insufficient for a vast continent, exceeding 14 million $\mathrm{km}^{2}$.

Permafrost in Antarctica is both present in ice-free areas of Maritime (Vieira et al., 2010; Bockheim et al., 2013) and Continental Antarctica (Bockheim and Hall, 2002), as well as beneath the ice-sheet where subglacial permafrost exists (Bockheim and Hall, 2002). However, it is in ice-free environments of Maritime Antarctic where permafrost conditions are found in boundary climatic conditions. In the case of the South Shetland Islands (SSI), permafrost has not been generally detected in elevations below $20 \mathrm{~m}$ a.s.l. but has been found widespread above 40 m a.s.l. (Serrano, 2003; Serrano et al., 2008; Ramos et al., 2009; Vieira et al., 2010). Therefore, a transition belt with sporadic or discontinuous was established in the SSI between 20 and 40 m a.s.l. Nevertheless, local 
factors can induce changes in this general distribution. In the SSI geomorphological landforms features related to permafrost conditions, such as rock glaciers, protalus lobes or moraines with ice-rich permafrost, have been observed close to sea level (López-Martínez et al., 2012; Oliva and Ruiz-Fernández, 2015).

Vegetation cover also can generate a strong control on permafrost distribution and active layer dynamics. In discontinuous permafrost regions there is a close relationship between vegetation assemblages and the existence or absence of permafrost conditions in the area (Dingman et al., 1974). A tundra-type vegetation has also a strong impact on active layer thaw since it intercepts incoming radiation (Kelley et al., 2004). Besides, the distribution of snow across the landscape can alter active layer dynamics and induce changes on the vegetation communities (Johansson et al., 2013). However, it is necessary to note that in the Maritime Antarctic the vegetation forms an open tundra (Serrano, 2003), sparser than other types of tundra.

Most of these studies have used geomorphological indicators or boreholes data to determine the permafrost conditions. However, there are other methods that can provide accurate data on the distribution of permanent frozen ground conditions. In this regard geoelectrical methods can be useful in detecting and delineating permafrost and/or frozen ground and space and time evolution (Hauck and Kneisel, 2008). Field and laboratory data indicates that electrical resistivity of rocks and soil increase several times after freezing temperature is reached (Hoekstra et al., 1975; Olhoeft, 1978; Scott et al., 1990; Vanhala et al., 2009). Depending on the salts content freezing can take place at temperatures lower than $0{ }^{\circ} \mathrm{C}$ and the electrical resistivity increases slowly until all water is frozen; after complete freezing rocks and soil generally present very high electrical resistivities. The use of geoelectrical methods for detecting permafrost must also consider that electrical resistivities depend on ground ice content.

The main objective of this research is to evaluate the present-day distribution of permafrost conditions in Byers Peninsula (Livingston Island), the largest ice-free environment in the SSI archipelago, along a topographic gradient from sea level to Sealer Hill, a summit plateau at $91 \mathrm{~m}$ a.s.l. in the SE area of Byers Peninsula. We analysed the geoecological settings along this transect in order to understand the relationship between the geomorphic features and the biological activity. The geophysical surveying was carried out along the raised beaches transect of this profile to infer the distribution of frozen ground conditions at the coastal zone. Also, we discussed how the distribution of permafrost conditions in Byers fits the geographical pattern of frozen ground conditions in the SSI.

\section{Study area}

The study area is located in Byers Peninsula (between $62^{\circ} 34^{\prime} 35^{\prime \prime} \mathrm{S}-$ $62^{\circ} 40^{\prime} 35^{\prime \prime} \mathrm{S}$ latitude and $60^{\circ} 54^{\prime} 14^{\prime \prime} \mathrm{W}-61^{\circ} 13^{\prime} 07^{\prime \prime} \mathrm{W}$ longitude) in Livingston Island. With $\sim 60 \mathrm{~km}^{2}$, this ice-free environment is the largest of the SSI. This archipelago is composed of 11 main islands located 120$130 \mathrm{~km} \mathrm{NW}$ of the tip of the Antarctic Peninsula (AP) (Fig. 1). About $90 \%$ of these islands is covered by glaciers (Serrano, 2003). The icefree environments correspond mostly to nunataks and small peninsulas distributed along the coastal fringes of those islands. It is in these deglaciated terrestrial ecosystems of Maritime Antarctica where biodiversity is greatest (Convey and Smith, 2006).

Climatic conditions in Byers Peninsula are characterized by a maritime polar regime, with relatively abundant annual precipitations between 500 and $800 \mathrm{~mm}$ mainly as snow. The mean annual temperature is about $-2{ }^{\circ} \mathrm{C}$ at sea level (Bañón et al., 2013). In Byers Peninsula the relief is organized on a series of stepper platforms reaching elevations of 70-100 $\mathrm{m}$ a.s.l. in the central plateau. They are composed of volcanic, volcanoclastic, and detritic materials (mainly sandstones, mudstones, and conglomerates) of Jurassic and Cretaceous age, as well as intrusive rocks such as sills and dikes of Cretaceous age (Smellie et al., 1980, 1984; Hathway and Lomas, 1998; Parica et al., 2007). These platforms are surrounded by seven levels of Holocene raised beaches (Arche et al., 1996; López-Martínez et al., 1996; Hall and Perry, 2004; Moura et al., 2012). Some volcanic plugs stand out from the central plateau, such as Cerro Negro (143 m a.s.l.), Cerro Penca (217 m a.s.l.) or Cerro Start (265 $\mathrm{m}$ a.s.l.), which constitutes the highest elevation in the peninsula. The present-day geomorphological dynamics is strongly influenced by the presence of permafrost and the annual evolution of the active layer. Consequently, periglacial activity, such as solifluction, frost shattering, cryoturbation, and nivation processes are widespread.

Byers Peninsula has been defined as one of the terrestrial ecosystems of Antarctica with greatest biodiversity (Toro et al., 2007). The vegetation consists of an open tundra composed of several species of mosses and lichens (Lindsay, 1971; Serrano, 2003). Moreover, the two only autochthonous vascular plants in Antarctica (Deschampsia antarctica and Colobanthus quitensis) are also present in Byers Peninsula (Vera, 2011; Vera et al., 2013), especially abundant in the lowest raised beaches.

Human impact in Byers has been limited and restricted to the shelters built by the sealers and whalers that visited the coastal areas of the SSI at the end of the 18th and first decades of the 19th centuries (Zarankin and Senatore, 2005). Since the early 2000s, scientific activities in Byers Peninsula have been numerous, always limited to a small number of researchers and to the summer season. Taking into account its geological and biological heritage, Byers Peninsula was declared Antarctic Specially Protected Area number 126 in 1966 within the framework of the Antarctic Treaty.

This work focuses on the SW corner of Byers Peninsula, particularly in the Sealer Hill area and the raised beaches distributed in its eastern side. The Sealer Hill (91 $\mathrm{m}$ a.s.l.) is composed of a basalt plug showing columnar jointing (Parica et al., 2007).

\section{Materials and methods}

Field work was conducted in late January 2015 after a snowy year in the SSI, which conditioned research activities in the field as well as the results obtained and presented in this paper. A geomorphological sketch of the landforms along a transect from sea level to Sealer Hill was carried out in the field together with the support of a high resolution WorldView2 satellite image of Byers Peninsula from 2-1-2011. These data were compared also with geoecological observations conducted in the field along the same area following the approach proposed by Troll (1968, 1972), implemented in Antarctica by several authors (e.g. Serrano, 2003; Oliva et al., 2016a, b). These observations consisted in the identification of the vegetation communities in the area examining their distribution with regards to topography and geomorphology.

To try to detect and delineate possible permafrost or frozen ground a geoelectrical survey using an electrical resistivity tomography (ERT) approach was used. Initially, the idea was to obtain an electrical resistivity transect from the sea shoreline to the top of the Sealer Hill (Fig. 2) along a NW-SE direction approximately. To accomplish that four ERT profiles were done in such a way that the first half of the second ERT profile would overlap the second half of the first ERT profile, the second half of the second ERT profile would overlap the first half of the third ERT profile, and so on until the end of the fourth profile. The overlapping profiles were composed in a $158 \mathrm{~m}$ long profile which was then processed to obtain the geoelectrical model shown in Fig. 3. Each ERT profile was done using 40 stainless electrodes spaced by $2 \mathrm{~m}$, each one with an active electrode. An earth resistivity meter "4point light 10 W", manufactured by LGM LIPPMANN was used to control the measuring process with a chain of 40 active electrodes and record the field data which were downloaded latter for processing. During the acquisition state a few problems related with high electrical contact resistances between the ground and the stainless electrodes had to be solved. By eye inspection those problems were the result of frozen ground or dried mosses. Those problems were solved by watering with sea water the zone of the electrodes affected by high electrical contact resistance. 

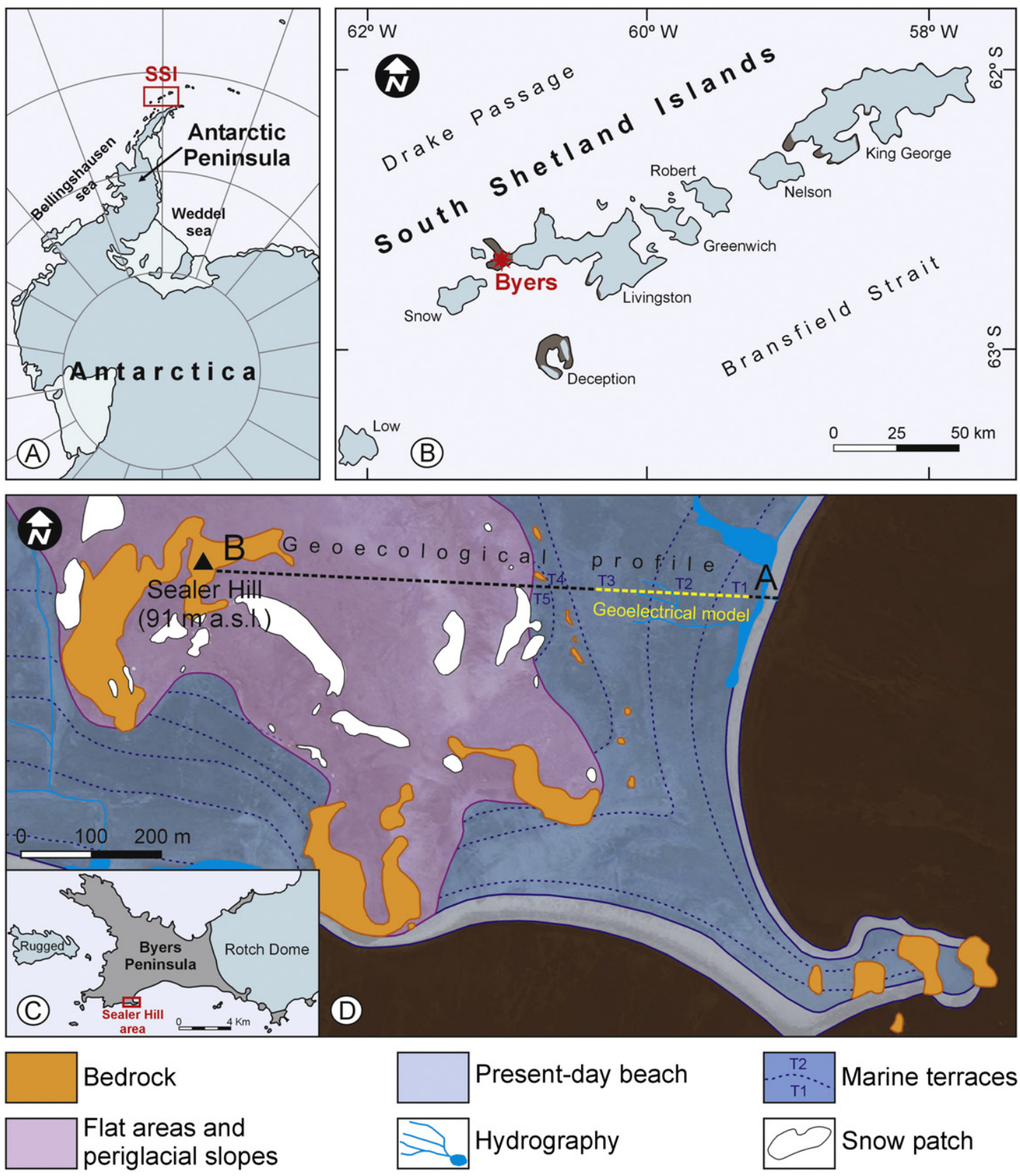

Fig. 1. Location of the SSI within Antarctica (A), Byers Peninsula within the SSI (B), Sealer Hill within Byers Peninsula, and (D) geomorphological sketch of Sealer Hill area.
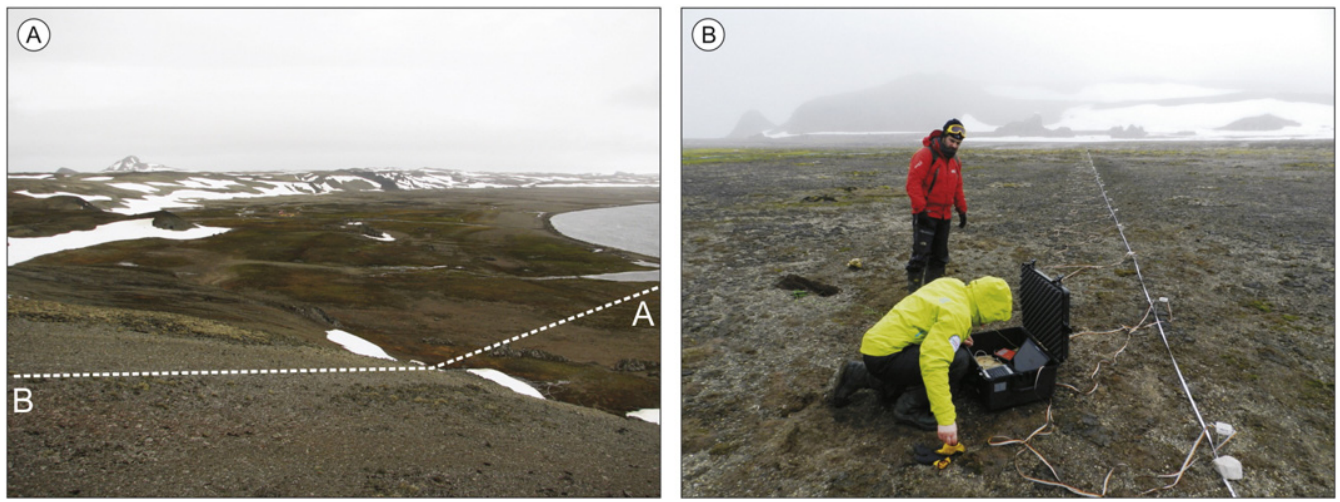

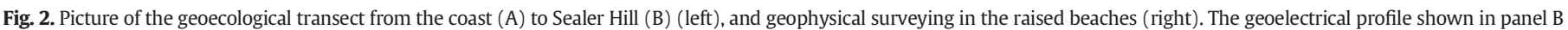
coincides with the yellow dashed line drawn in Fig. 1. 


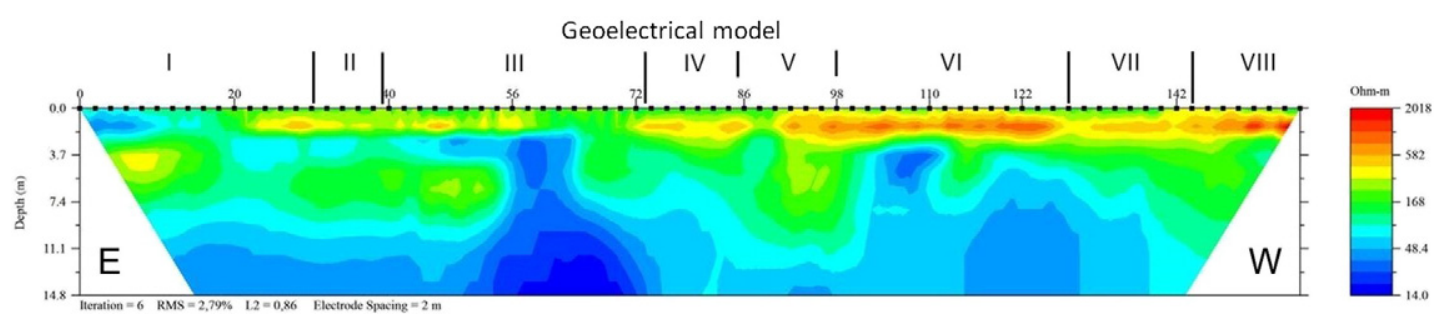

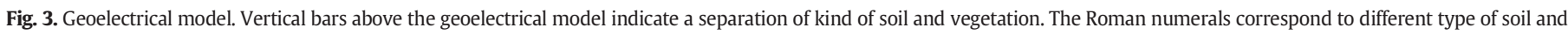
vegetation which are described in Table 2.

It should be mentioned that in the geoelectrical model of Fig. 3 only ERT profiles 2, 3, and 4 were used; ERT profile 1 could not be included in the geoelectrical transect because the data show inconsistencies which appear to be a result of parasitic electrical potentials generated by the interaction of snow-melt water flowing towards the sea and the seawater in the sea shoreline. The geoelectrical data were processed using the EarthImager 2D resistivity inversion software.

\section{Results}

\subsection{Geophysical transect}

Fig. 3 shows the electrical resistivity model obtained by inversion of apparent electrical resistivities measured along the transect shown in Fig. 2. The data showed a good quality; the RMS of the inversion of the three merged ERTs is $2.8 \%$ and the individual RMS of each ERT is lower than $2 \%$. Besides this, the measurements showed high stability and reproducibility during the field work.

From the model (Fig. 3) it is apparent that high electrical resistivities are located near the surface of the model and increase in size and depth as one goes inland. Along the geoelectrical profile, patches of high electrical resistivity vary from about $800 \Omega \cdot \mathrm{m}$, between 73 and $86 \mathrm{~m}$, to about $2000 \Omega \cdot \mathrm{m}$, from 92 to $126 \mathrm{~m}$ and again from $148 \mathrm{~m}$ until the end of the profile. So, in general terms, it can be said that electrical resistivity increases from near shore to inland.

Low electrical resistivities can be found near the shore line and deeper in the geoelectrical profile. It appears that the depth of about $1.8 \mathrm{~m}$ is the limit of the high electrical resistivities measured along the geoelectrical profile. At depth, electrical resistivity values are significantly lower than at the surface, reaching electrical resistivities lower than $100 \Omega \cdot \mathrm{m}$ between 4 and $15 \mathrm{~m}$ depth. However, the pattern of electrical resistivities is complex and probably results from a complex interaction of melt water, sea water, and changes in ground porosity.

Superimposed in the geoelectrical model there is a general description of the landforms and vegetation (Table 2) that were observed along the geoelectrical profile (Fig. 3). Even though the distribution of vegetation along the profile was not done with great detail, one fact is apparent from the superimposition of the density of vegetation in the geoelectrical profile: in general terms high electrical resistivities appear to be coincident with high vegetation density, which increases inland (Fig. 4).

\subsection{Geomorphological and geoecological setting}

Three main environments were identified along a transect from the beach to Sealer Hill in the SE corner of Byers Peninsula (Fig. 1).

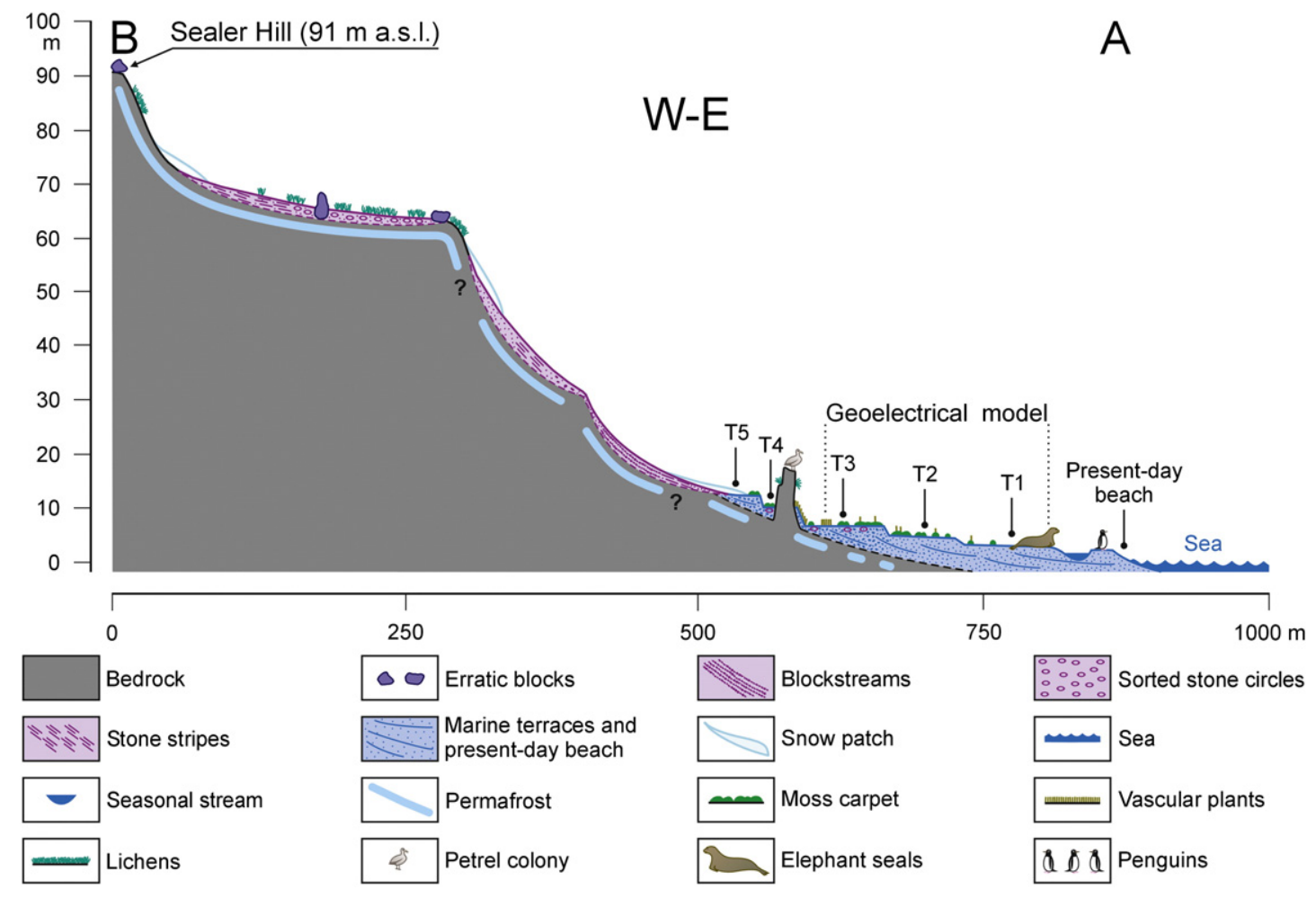

Fig. 4. Geoecological sketch from the beach (A) to Sealer Hill (B). 


\subsubsection{Raised beaches}

A sequence of five raised beaches was observed in this sector and throughout Byers Peninsula, with the ridges being situated at elevations of 3, 4-5, 6, 10 and $12 \mathrm{~m}$ a.s.l. (Table 1; Fig. 1; Arche et al., 1996; Hall and Perry, 2004). The distance between both risers in each terrace level ranges from 35 to $102 \mathrm{~m}$. Whereas T1 to T4 showed fine-grained sediments in their surface, $\mathrm{T} 4$ and $\mathrm{T} 5$ presented many boulders with rounded to subangular morphology. Evidence of intense cryogenic activity was detected across T3, where mudboils composed mostly of finegrained sediments were frequent. On T4 mudboils were also observed although they were scarce due to the abundance of coarser materials. On T5 mudboils were not present since this terrace consisted of very coarse sediments (pebbles and blocks).

In the steeper upper levels long-lying snow patches were still large by the end of January 2015, which favoured the drainage of water down-slope and its accumulation in the relatively flat surfaces of the raised beaches. Here, in these poorly drained areas vegetation cover was mainly composed of mosses (mainly Sanionia uncinata, Warnstorfia laculosa, Warnstorfia sarmentosa), while the higher better-drained terraces were covered with an herbaceous community consisting mainly of Deschampsia antarctica and Colobanthus quitensis, and to a lesser extent of bryophytes such as Polytrichastrum alpinum and Polytrichum piliferum (Fig. 5). However, areas devoid of vegetation cover were abundant, especially on the lower terraces. In the small rock outcrops dividing T3 from T4, several species of lichens are present, such as Usnea aurantiaco-atra, Ramalina terebrata, Rhizocarpon geographicum, Peltigera rufescens, Umbilicaria antarctica and Umbilicaria decussata. Here, the existence of a colony of southern giant petrels (Macronectes giganteus) favours the development of ornitocoprophilous lichens, such as Haematomma erythromma, Caloplaca regalis and Xanthoria elegans (Fig. 4).

\subsubsection{Hill slopes}

The steep slopes connecting the plateau surface of Sealer Hill with the upper marine terrace T5 (Fig. 4) show a slope ranging between 30 and $35^{\circ}$. A significant part of the slopes was still covered with snow in late January 2015. The uppermost part of the southern face of this volcanic plug constitutes a nivation hollow. Inside the nivation hollow, the snow-free areas showed abundant unconsolidated rock fragments, with pebbles and cobbles interbedded in a sandy matrix. The uppermost sediments were water-saturated, which favoured mass-wasting activity. Traces of down-slope transport of particles were observed, such as the orientation of the clasts down slope. In the upper part of the hollow the effective physical weathering processes provided abundant shattered rock fragments detached from the basalt outcrops of Sealer
Table 2

Description of the soil and vegetation observed along the geoelectrical profile of Fig. 3. Roman numbers refer to the units shown in Fig. 3.

\begin{tabular}{|c|c|c|}
\hline $\begin{array}{l}\text { Distance } \\
(\mathrm{m})\end{array}$ & Units & Geographical and ecological characteristics \\
\hline $0-30$ & I & No vegetation. Flooded area. \\
\hline $30-39$ & II & $\begin{array}{l}\text { Isolated mats of mosses. Presence of isolated examples of } \\
\text { Deschampsia antarctica on these mats. Fine grained sediments, } \\
\text { mostly sands and some gravels. }\end{array}$ \\
\hline 39-73 & III & Dead mosses. Intermittent flooded areas. \\
\hline $73-85$ & IV & $\begin{array}{l}\text { Isolated mats of mosses with incipient lichens on the top of the } \\
\text { mats. }\end{array}$ \\
\hline $85-98$ & $\mathrm{~V}$ & $\begin{array}{l}\text { Dead mosses, intermittent flooded areas. Limit of the raised } \\
\text { beach. Starting at } 98 \mathrm{~m} \text { begins the next raised beach level, } \\
\text { separated from the first by a shallow escarpment. }\end{array}$ \\
\hline $98-128$ & VI & $\begin{array}{l}\text { Mats of mosses, with Deschampsia antarctica in the upper parts } \\
\text { of the mat (lower moisture conditions). }\end{array}$ \\
\hline $128-144$ & VII & Dead mosses. Still in the second level of raised beaches. \\
\hline $144-158$ & VIII & Mats of mosses, with Deschampsia Antarctica. \\
\hline
\end{tabular}

Hill. Cryogenic processes were also intense on the slope, where cryoturbation features such as stone stripes are widespread (Fig. 6). Active blockstreams with no lichen cover are abundant at elevations between 18 and $39 \mathrm{~m}$ a.s.l. Stone-banked solifluction lobes are also present. The high instability of the sediments does not allow the existence of vegetation.

\subsubsection{Plateau surface}

The highest surface at Sealer Hill constitutes a relatively flat terrain, with moderately shallow cryosols (ornithogenic) and rocky crests. Soils are composed of a sandy-silty texture, which favour the geomorphic effects of freezing and thawing activity in the ground. Cryoturbation phenomena are abundant, particularly stone stripes in gentle slopes $\left(6-7^{\circ}\right)$ and sorted stone circles in flat areas (Fig. 6). At top of Sealer Hill we observed erratic boulders of allochthonous lithologies such as mudstones, as well as clear traces of glacial abrasion on the bedrock surface. In this environment a cryptogamic community composed mainly of Usnea aurantiaco-atra developed together with the moss Andreaea gainii (Fig. 5). In the rocky surfaces occupied by petrel colonies, crustose nitrophilous lichens are dominant such as Haematomma erythromma. In the hilly surfaces there is a clear correlation between the absence of Usnea aurantiaco-atra in concave depressions where snow accumulates and the wind-exposed slopes with less snow cover; this has been already observed in other ice-free maritime polar environments of the SSI (Vieira et al., 2014).

Table 1

Altitude, slope angle and characteristics of the five different levels of raised beaches observed in the study area.

\begin{tabular}{|c|c|c|c|c|}
\hline Level & $\begin{array}{l}\text { Altitude } \\
(\mathrm{m})\end{array}$ & $\begin{array}{l}\text { Riser, slope } \\
\text { angle }\left({ }^{\circ}\right)\end{array}$ & $\begin{array}{l}\text { Distance } \\
(\mathrm{m})\end{array}$ & Geoecology \\
\hline $\mathrm{T} 1$ & 3 & 12 & 98 & $\begin{array}{l}\text { It mainly consists of sands and gravels with presence of small pebbles. The flooded areas are colonized by mosses such as } \\
\text { Sanionia uncinata, Warnstorfia laculosa and Warnstorfia sarmentosa. Dead mosses are also abundant. On moss mats there are } \\
\text { isolated specimens of Deschampsia antarctica. Across T1 there are also elephant seals (Mirounga leonina) and birdlife such as } \\
\text { penguins (Pygoscelis papua, Pygoscelis antarctica), southern giant petrels (Macronectes giganteus) and kelp gulls (Larus dominicanus). }\end{array}$ \\
\hline $\mathrm{T} 2$ & $4-5$ & 15 & 75 & $\begin{array}{l}\text { The size of the sediments is similar to T1. The degree of vegetation cover slightly increases upslope towards T3. Isolated moss } \\
\text { mats and moss carpets are distributed across the terrace. Presence of elephant seals and penguins. }\end{array}$ \\
\hline T3 & 6 & $35-40$ & 102 & $\begin{array}{l}\text { Vast flat terrace crossed by several small seasonal streams draining the snow-melt runoff. Presence of landforms generated by } \\
\text { cryogenic activity (mudboils). Existence of moss mats typical of moist environments (e.g. Andreaea gainii, Andreaea depressinervis, } \\
\text { Pohlia nutans, Polytrichastrum alpinum, Polytrichum piliferum) and frequent patches of Deschampsia antarctica and Colobanthus } \\
\text { quitensis. The riser between T3 and T4 is covered with an herbaceous community mainly composed of Deschampsia antarctica. }\end{array}$ \\
\hline $\mathrm{T} 4$ & 10 & $30-55$ & 40 & $\begin{array}{l}\text { Steep riser with long-lasting snow patches at the lower part of the terrace in contact with rocky outcrops. A colony of southern } \\
\text { giant petrels is present on these outcrops. Here, ornitocoprophilous lichens such as Haematomma erythromma, Caloplaca regalis } \\
\text { and Xanthoria elegans are abundant. The terrace presents a patchy moss cover. }\end{array}$ \\
\hline T5 & 12 & $15-20$ & 35 & $\begin{array}{l}\text { It is the highest raised beach in contact with the steep slopes descending from Sealer Hills. Poorly drained areas, with abundant } \\
\text { water from surrounding snow patches. Vegetation cover is scarce. }\end{array}$ \\
\hline
\end{tabular}



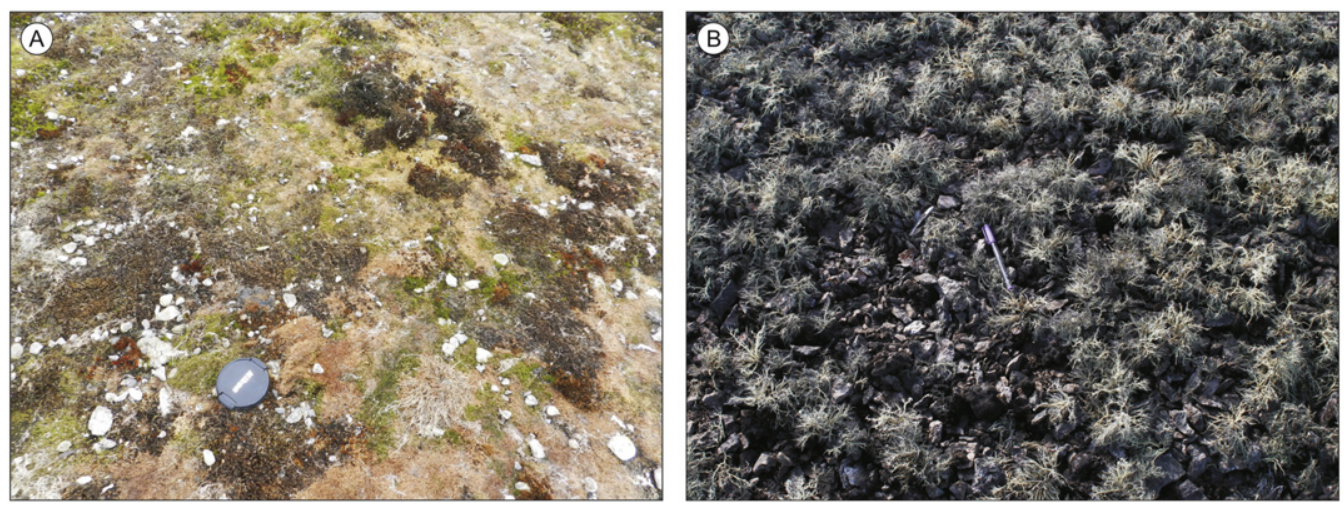

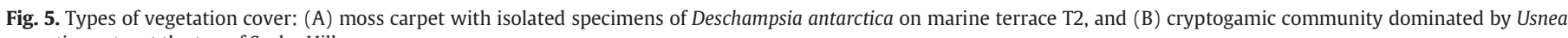
aurantiaco-atra at the top of Sealer Hill.

\section{Discussion}

\subsection{Permafrost distribution based on geophysical methods}

In general terms there is an average slow increase of the size and thickness of the more resistive patches observed along the geoelectrical model of Fig. 3 inland. These high electrical resistivity patches reached values of about $2000 \Omega \cdot \mathrm{m}$, which are interpreted as sporadic permafrost conditions. As a matter of fact, frozen ground was detected by eye inspection when trying to decrease the electrical contact resistance between the stainless electrodes and the ground when doing the field work.

It is interesting to note that in the neighbouring Deception Island an electrical resistivity survey using electrical resistivity tomographies and vertical electrical soundings allow to determine that, in the shore near the Crater Lake 70 area (a couple of hundred meters from the shore line), electrical resistivities of permafrost would start at about $1300 \Omega \cdot \mathrm{m}$ (Correia et al., 2014); there permafrost top was about 50$70 \mathrm{~cm}$ deep which was verified by ground truthing. A vertical electrical sounding done in the same area indicates that the sediments soaked in sea water presented an electrical resistivity of $0.5 \Omega \cdot \mathrm{m}$ at depths of about $24 \mathrm{~m}$. A transition layer of about $600 \Omega \cdot \mathrm{m}$, about $15 \mathrm{~m}$ thick would separate the permafrost layer from the sea water saturated sediments. These two results obtained for Deception Island suggest that sea water can intrude the sediments at coastal areas interacting with frozen ground/permafrost.

In Fig. 3 the low resistivities (below $100 \Omega \cdot \mathrm{m}$ ) detected between 4 and $15 \mathrm{~m}$ depth can be related to the intrusion of salty waters in the deeper layers of the area. In fact, the profiles were conducted at elevations of a couple of meters a.s.l. which means that these layers are located below sea level. Sea water intrusion in the deep layers of the
Holocene raised beaches of Byers Peninsula can, therefore, condition the existence of these low resistivities and the existence of permafrost. However, as can be seen in Fig. 3, the pattern of distribution of the electrical resistivity is complex with a saline front difficult to detect. As a matter of fact, as in Deception Island, the sea water electrical resistivity should be around $0.5 \Omega \cdot \mathrm{m}$ and the lowest electrical resistivities in Fig. 3 are about $14 \Omega \cdot \mathrm{m}$. A possible explanation for not detecting the saline front in Byers is the facies difference of the raised beaches in Byers and in Deception Island; as a matter of fact, at least at the surface, sediments in Byers appear to be finer than in Deception Island which might generate lower permeabilities and so create higher electrical resistivities.

An interesting result of the geoelectrical survey is that there appears to be a coincidence (at least in average terms) between high electrical resistivities and the vegetation just above the high electrical resistivity patches. Actually, up to $73 \mathrm{~m}$ inland, the geoelectrical profile crossed flooded zones with isolated mats of mosses or dead mosses. From $73 \mathrm{~m}$ to the end of the geoelectrical profile (i.e., $158 \mathrm{~m}$ ) the amount of dead mosses or mats of mosses increase substantially. This increase in the density distribution of the mosses coincides with the increase of the electrical resistivity and thickness of the ground high electrical resistivities. The presence of a moss cover affects the soil heat transfer through thermal and hydrological insulation depending on the thickness and wetness of the moss (Ekici et al., 2014). Even though the vegetation cover along the geoelectrical profile is sparse, its influence in maintaining temperatures below freezing point can be seen using the electrical method and could be verified by eye inspection (at least in the zone where some stainless electrodes were forced into the ground). The spatial difference in the geographical distribution of the moss cover brings an additional heterogeneity to the soil thermal properties and dynamics in a small area (Ekici et al., 2014). This result confirms other
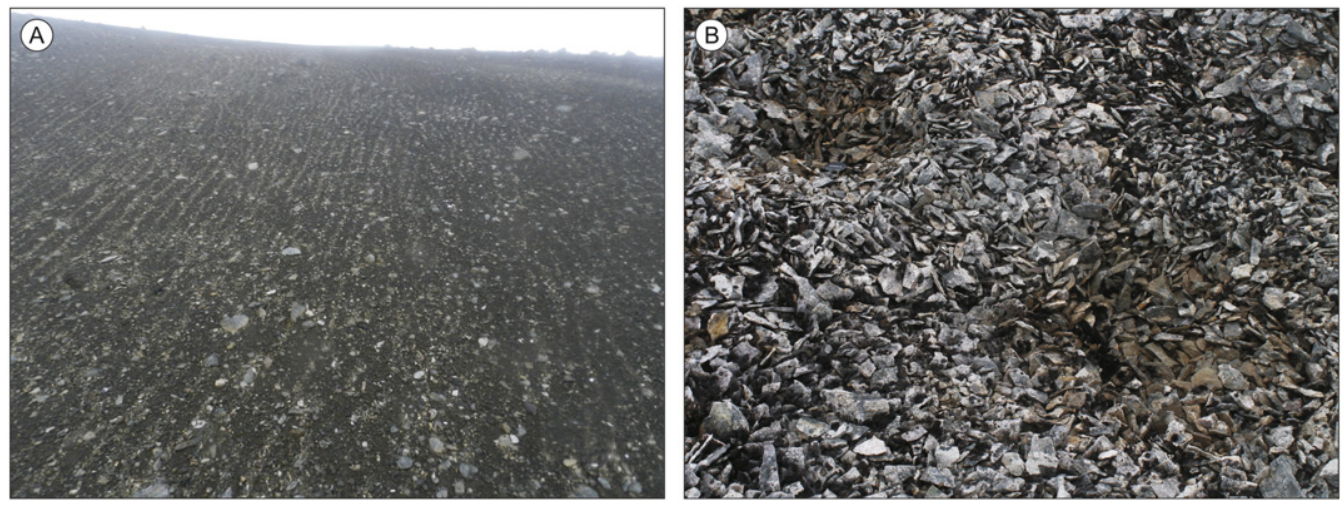

Fig. 6. Examples of intense cryoturbation processes around the Sealer Hill: (A) stone stripes at the hillslope, and (B) stone sorted circles in a flat area at the top. 
observations in other regions with permafrost which show that vegetation cover and, in particular, mosses are natural insulators and maintain the ground temperature lower than if there were no mosses (Sharkhuu and Sharkhuu, 2012). Moreover, the presence of a frozen layer in the subsurface affects soil infiltration since more water is stored in the active layer and favours moss development (Beringer et al., 2001).

Apart from the correspondence between frozen ground and vegetation, its distribution across the transect is influenced by several factors such as the age of deglaciation, drainage conditions, geomorphology activity, soil moisture content and microclimatic conditions (i.e. exposure to prevailing winds). Besides, topography also affects the existence of snow and frozen ground conditions. In general, the vegetation cover increases from the lowest to the highest (and oldest) raised beaches. On poorly drained areas mosses typical of water-saturated areas are widespread, such as Sanionia uncinata. In moist areas with lower soil moisture content other type of mosses prevail (Andreaea gainii, Andreaea depressinervis, Polytrichastrum alpinum, Polytrichum piliferum, etc.), while the well-drained sites areas of the terraces include an herbaceous community characterized by the predominance of Deschampsia antarctica. However, this distribution is disrupted by the existence of semipermanent snow patches and seasonal streams in the higher terraces, where non-vegetated sites are also common. On the other hand, the hill slope is devoid of vegetation because periglacial slope processes are very active remobilizing sediments. Finally, the Sealer Hill plateau is a wind-exposed surface where the wind action redistributes the snow. This area is covered by a cryptogamic community composed mainly by Usnea aurantiaco-atra. However, as shown by Vieira et al. (2014), in concave depressions where snow remains longer, these lichens are absent or scarce. Finally, another local factor that plays a decisive role in the development of the vegetation cover is the presence or absence of fauna. In the vicinity of penguins, petrels and elephant seal colonies the soil received abundant nutrient.

\subsection{Permafrost distribution based on geomorphological indicators}

The land surface in the ice-free environments in the SSI is strongly influenced by the presence of permafrost. Permanent frozen conditions are absent in coastal areas up to $20 \mathrm{~m}$ a.s.l. but discontinuous permafrost has been detected at elevations between 20 and $40 \mathrm{~m}$ a.s.l. and continuous permafrost regime exists at higher altitudes (Serrano, 2003; Serrano et al., 2008; Ramos et al., 2009; Vieira et al., 2010; Bockheim et al., 2013). Even in areas where the thermal regime of the ground is characterized by seasonal frost, periglacial processes are widespread in all ice-free areas in Maritime Antarctica, with a wide range of landforms and processes showing intense activity. In some areas in the SSI permafrost-related features, such as protalus lobes and rock glaciers, have been detected at almost sea level, as well as other features indicative of the presence of ground ice (Bockheim and Hall, 2002; Serrano and López-Martínez, 2000; Serrano et al., 2008; Bockheim et al., 2013). Near Byers Peninsula, in the close ice-free peninsula of Elephant Point, an ice-cored moraine and thermokarst processes undergoing a process of degradation are distributed at elevations below $5 \mathrm{~m}$ a.s.l. (Oliva and Ruiz-Fernández, 2015).

In Byers Peninsula permafrost conditions have been only reported in the central plateau at elevations between 35 and $100 \mathrm{~m}$ a.s.l. with an active layer ranging from 0.9 to $1.5 \mathrm{~m}$ depth (Serrano et al., 1996; de Pablo et al., 2013, 2014; Oliva et al., 2016a). The data presented in this study suggest that the Holocene raised beaches surrounding the central plateau of Byers may also be underlined by patches of permafrost several meters thick (Fig. 3). No clear geomorphic indicators were observed along the transect on the raised beaches that confirm the existence of permafrost from a geomorphological point of view. However, at the foot of the Cerro Negro hill ( $3 \mathrm{~km}$ distance), incipient ice-wedge polygonal terrain with visible evidence of recent frost cracking were observed in 2014 (Ruiz-Fernández and Oliva, 2016). Some minor periglacial features related to intense cryoturbation (sorted stone circles, stone stripes) were observed in the area, but these features are not strictly associated to permafrost conditions.

The presence of patchy permafrost conditions at elevations of ca 4$5 \mathrm{~m}$ a.s.l. on Holocene raised beaches must be also interpreted in terms of the time necessary for their development. According to geophysical data these frozen ground conditions are not deeper than about $1.8 \mathrm{~m}$ in the area where the ERTs were done (Fig. 3). The fact that the vast area covered by the marine terraces distributed until $6 \mathrm{~m}$ a.s.l. in the SW corner of Byers Peninsula emerged only over the last $500 \mathrm{yr}$ cal BP (Hall and Perry, 2004) suggests that the frozen ground conditions that only appear in the uppermost stretch of the transect, at elevations of 4-5 $\mathrm{m}$ a.s.l. (Fig. 3), must have developed over the last centuries, only after the land surface was exposed to atmospheric conditions. The last $500 \mathrm{yr}$ include periods with glacier expansion in the northern Antarctic Peninsula, namely during the Little Ice Age between 1500 and 1700 CE (Hjort et al., 2003; Yoon et al., 2004; Simms et al., 2012). Some moraines systems in Livingston Island (Serrano and López-Martínez, 1997; Martínez de Pisón, 2000), and also in Byers Peninsula (López-Martínez et al., 1996) have been attributed to the LIA. This period was characterized by colder and wetter conditions which may have driven a decrease in altitude of the lower permafrost boundary in the SSI favouring the formation of the permafrost patches still existing today in the raised beaches in Byers Peninsula. The increasing temperatures of the last half century (Turner et al., 2005) may have degraded these permanent frozen conditions and only some thin remnants of permafrost still persist in areas where snow patches last longer and keep soil temperatures lower.

Along the slopes descending from Sealer Hill the presence of active blockstreams at elevations between 18 and $39 \mathrm{~m}$ a.s.l. may suggest the lower elevation limit of discontinuous/continuous permafrost condition in the SW corner of Byers Peninsula. In the summit plateau of Sealer Hill sorted stone circles and stone stripes are particularly abundant; even if there are no geomorphic indicators indicating the existence of permafrost in this site, the elevation of this site (ca. $90 \mathrm{~m}$ a.s.l.) - clearly above the altitudinal range of permafrost existence according to previous studies in Byers Peninsula (Serrano et al., 1996, 2008; Serrano, 2003; de Pablo et al., 2013, 2014; Oliva et al., 2016a) - suggests that permafrost is widespread across the summit surface of Sealer Hill. Moreover, the existence of allochthonous materials and glacial striations suggests former over-riding glaciation in the SW corner of Byers Peninsula.

\section{Conclusions}

Permafrost plays a key role on geomorphological and geoecological processes prevailing in ice-free environments in Maritime Antarctic. However, data on permafrost distribution across the AP region are scarce and only limited to geomorphological observations and monitoring data from a reduced number of sites. With the purpose of complementing the existing knowledge on permafrost distribution in the lowland areas of the SSI, in January 2015 we conducted a geoelectrical survey on the Late Holocene raised beaches distributed across Byers Peninsula, Livingston Island, combined with a geoecological approach.

The experiment was carried out in late January 2015 after a snowy year in the SSI, and therefore the data must be interpreted within this context. An electrical resistivity tomography has shown that several patches of medium/high electrical resistivity are found along a geoelectrical profile $158 \mathrm{~m}$ long. The profile crossed two marine terrace levels distributed at elevations of 3 and $4-5 \mathrm{~m}$ a.s.l. As observed in other permafrost environments, the high electrical resistivity patches $(\sim 2000 \Omega \cdot \mathrm{m})$ are interpreted as sporadic permafrost patches at elevations close to sea level, i.e., of only $4-5 \mathrm{~m}$ a.s.l. These high electrical resistivity values coincide, at the surface, with patches of mosses (dead or not) which suggest that, to some extent, the structure of the frozen ground is correlated with the vegetation cover. Therefore, the geoelectrical survey also suggests that the lower limits of sporadic 
permafrost in the area were crossed, which is close to the shoreline in this ice-free environment region. Geomorphological observations, such as the presence of active blockstreams in the southern slope of the Sealers Hill, support the idea that permafrost conditions are close to the elevation site.

The relatively flat relief of the Holocene raised beaches at Byers Peninsula and the gentle to moderate slopes with permafrost-related features, represent a unique area for evaluate the altitudinal boundaries between sporadic, discontinuous and continuous permafrost belts in Maritime Antarctica.

\section{Acknowledgements}

This research has been funded by the Portuguese Science Foundation (PTDC/CTE-GIX/119582/2010) through the research project HOLOANTAR (Holocene environmental change in the Maritime Antarctic. Interactions Between permafrost and the lacustrine environment) and the Portuguese Polar Program (PROPOLAR). We are grateful to the Chilean Antarctic Institute (INACH) for providing logistic support of field work activities. M. Oliva acknowledges the AXA Research Fund for funding his research activities in Antarctica. The authors also acknowledge and thank the comments and suggestions of Enrique Serrano, Carlos Schaefer, and Matt Strzelecki.

\section{References}

Arche, A., López-Martínez, G., Serrano, E., Martínez de Pisón, E., Martínez de Pisón, E. Serrano, E., Zale, R., King, S., 1996. Marine landforms and deposits. In: LópezMartínez, J., Thomson, M.R.A., Arche, A., Björck, S., Ellis-Evans, J.C., Hathway, B., Hernández-Cifuentes, F., Hjort, C., Ingolfsson, O., Ising, J., Lomas, S. (Eds.), Geomorphological Map of Byers Peninsula, Livingston Island. British Antarctic Survey, Cambridge, pp. 35-42.

Bañón, M., Justel, A., Velázquez, D., Quesada, A., 2013. Regional weather survey on Byers Peninsula, Livingston Island, South Shetland Islands. Antarctica. Antarctic Sci. 25, 146-156.

Beringer, J., Lynch, A.H., Chapin, F.S., Mack, M., Bonan, G.B., 2001. The representation of Arctic soils in the land surface model: the importance of mosses. J. Clim. 14, 3324-3335.

Bockheim, J., Hall, K.J., 2002. Permafrost, active-layer dynamics and periglacial environments of continental Antarctica. S. Afr. J. Sci. 98, 82-90.

Bockheim, J., Vieira, G., Ramos, M., López-Martínez, J., Serrano, E., Guglielmin, M. Wilhelm, K., Nieuwendam, A., 2013. Climate warming and permafrost dynamics in the Antarctic Peninsula region. Glob. Planet. Chang. 100, 215-223.

Convey, P., Smith, R.I.L., 2006. Responses of terrestrial Antarctic ecosystems to climate change. Plant Ecol. 182 (1-2), 1-10.

Correia, A., Vieira, G., Goyanes, G., David, A., 2014. Recent permafrost aggradation in Deception Island, Antarctica. Results of geoelectrical surveys in the area of Craters 70. In: Vieira, G., Pina, P., Mora, C., Correia, A. (Eds.), Book of Abstracts of EUCOP4, 4th European Conference on Permafrost, p. 332.

De Pablo, M.A., Blanco, J.J., Molina, A., Ramos, M., Quesada, A., Vieira, G., 2013. Interannual active layer variability at the Limnopolar Lake CALM site on Byers Peninsula, Livingston Island. Antarct. Sci. 25, 167-180.

De Pablo, M.A., Ramos, M., Molina, A., 2014. Thermal characterization of the active layer at the Limnopolar Lake CALM-S site on Byers Peninsula (Livingston Island), Antarctica. Solid Earth 5, 721-739.

Dingman, S.L., Fleetwood, R., Koutz, F.R., 1974. Relations among vegetation, permafrost, and potential insolation in Central Alaska. Arct. Antarct. Alp. Res. 6 (1), 37-47.

Ekici, A., Beer, C., Hagemann, S., Boike, J., Langer, M., Hauck, C., 2014. Simulating highlatitude permafrost regions by the JSBACH terrestrial ecosystem model. Geosci. Model Dev. 7, 631-647.

French, H.M., 2007. The Periglacial Environment. third ed. John Wiley, New York.

Haeberli, W., Nötzli, J., Arenson, L., Delaloye, R., Gärtner-Roer, I., Gruber, S., Isaksen, K., Kneisel, C., Krautblatter, M., Phillips, M., 2010. Mountain permafrost: development and challenges of a young research field. J. Glaciol. 56 (200), 1043-1058.

Hall, B.L., Perry, E.R., 2004. Variations in ice rafted detritus on beaches in the south Shetland Islands: a possible climate proxy. Antarct. Sci. 16, 339-344.

Harris, C., Vonder-Mühll, D., Isaksen, K., Haeberli, W., Sollid, J.L., King, L., Holmlund, P., Dramis, F., Guglielmin, M., Palacios, D., 2003. Warming permafrost in European mountains. Glob. Planet. Chang. 39 (3-4), 215-225.

Hathway, B., Lomas, S.A., 1998. The Upper Jurassic-Lower Cretaceous Byers Group, South Shetland Islands, Antarctica: revised stratigraphy and regional correlations. Cretac. Res. 19, 43-67.

Hauck, C., Kneisel, C., 2008. Applied Geophysics in Periglacial Environments. Cambridge University Press.

Hjort, C., Ingólfsson, Ó., Bentley, M.J., Björck, S., 2003. The Late Pleistocene and Holocene glacial and climate history of the Antarctic Peninsula region as documented by the land and lake sediment records - a review. Antarctic Res. Series 79, 95-102.
Hoekstra, P., Sellmann, P.V., Delaney, A., 1975. Ground and airborne resistivity surveys of permafrost near Fairbanks, Alaska. Geophysics 40, 641-656.

Johansson, M., Callaghan, T.V., Bosiö, J., Åkerman, H.J., 2013. Rapid responses of permafrost and vegetation to experimentally increased snow cover in sub-arctic Sweden. Environ. Res. Lett. 8, 035025.

Kelley, A.M., Epstein, H., Walker, D.A., 2004. Role of vegetation and climate in permafrost active layer depth in arctic tundra of Northern Alaska and Canada. J. Glaciol. Climatol. 26, 269-273.

Lindsay, D.C., 1971. Vegetation of the South Shetland Islands. British Antarctic Survey Bulletin 25, 59-83.

López-Martínez, J., Martínez de Pisón, E., Serrano, E., Arche, A., 1996. Geomorphological map of Byers Peninsula, Livingston Island. Geomap Series. British Antarctic Survey, Cambridge (UK) (Sheet 5-A).

López-Martínez, J., Serrano, E., Schmid, T., Mink, S., Linés, C., 2012. Periglacial processes and landforms in the South Shetland Islands (northern Antarctic Peninsula region). Geomorphology 155, 62-79.

Martínez de Pisón, E., 2000. El relieve de una vieja península volcánica en la Antártida: la Península de Byers en la Isla de Livingston. Ería 53, 247-257.

Moura, P.A., Francelino, M.R., Schaefer, C.R., Simas, F.N.B., de Mendonça, B.A.F., 2012. Distribution and characterization of soils and landform relationships in Byers Peninsula, Livingston Island. Maritime Antarctica Geomorphology 155-156, 45-54.

Olhoeft, G.R., 1978. Electrical Properties of Permafrost. Proceedings of 3rd International Conference on Permafrost, Edmonton, Canada, pp. 127-131.

Oliva, M., Ruiz-Fernández, J., 2015. Coupling patterns between paraglacial and permafrost degradation responses in Antarctica. Earth Surf. Process. Landf. 40 (9), 1227-1238.

Oliva, M., Hrbáček, F., Ruiz-Fernández, J., De Pablo, M.A., Vieira, G., Ramos, M., 2016a. Active layer dynamics in three sites with distinct topography in the Byers Peninsula (Livingston Island, Antarctica). Catena.

Oliva, M., Ruiz-Fernández, J., Zarankin, A., Casanova-Katny, M.A., Nofre, J., 2016b. Geoecology and historical heritage of the ice-free area of Elephant Point (Livingston Island, Antarctica). Proposal for future environmental protection. Geoheritage http://dx.doi.org/10.1007/s12371-016-0184-1.

Oliva, M., Pereira, P., Bockheim, J., Navas, A., 2014. Soil processes in cold-climate environments. Solid. Earth 5, 1205-1208.

Parica, C.A., Salani, F.M., Vera, E., Remesal, M., Césari, S.N., 2007. Geología de la formación Cerro Negro (Cretácico) en la isla Livingston: aportes a su geocronología y contenido paleontológico. Rev. Asoc. Geol. Argent. 62 (4), 553-567.

Ramos, M., Hassler, A., Vieira, G., Hauck, C., Gruber, S., 2009. Setting up boreholes for permafrost thermal monitoring on Livingston Island in the Maritime Antarctic. Permafr Periglac. Process. 20 (1), 57-64.

Romanovsky, V.E., Smith, S.L., Christiansen, H.H., 2010. Permafrost thermal state in the polar Northern Hemisphere during the international polar year 2007-2009: a synthesis. Permafr. Periglac. Process. 21 (2), 106-116.

Ruiz-Fernández, J., Oliva, M., 2016. Relative palaeoenvironmental adjustments following deglaciation of the Byers Peninsula (Livingstone Island, Antarctica). Arct. Antarct. Alp. Res. 48 (2), 345-359.

Scott, W.J., Sellmann, P.V., Hunter, J.A., 1990. Geophysics in the study of permafrost. In: Ward, S.H. (Ed.), Geotechnical and Environmental GeophysicsInvestigation in Geophysics No. 5 Vol. 1. Review and Tutorial, Society of Exploration Geophysicists Tulsa, pp. 355-384.

Serrano, E., Martínez de Pisón, E., Lopez-Martínez, J., 1996. Periglacial and nival landforms and deposits. In: López-Martínez, J., Thomson, M.R.A., Arche, A., Björck, S., Ellis-Evans, J.C., Hathway, B., Hernández-Cifuentes, F., Hjort, C., Ingolfsson, O., Ising, J., Lomas, S., Martínez de Pisón, E., Serrano, E., Zale, R., King, S. (Eds.), Geomorphological Map of Byers Peninsula, Livingston Island. British Antarctic Survey, Cambridge, pp. 28-34.

Serrano, E., López-Martínez, J., 1997. Evolución de las formas de relieve y los depósitos superficiales cuaternarios en la Isla Media Luna. Islas Shetland del Sur. Boletín Real Sociedad Española de Historia Natural (Sección Geológica) 93 (1-4), 207-218.

Serrano, E., 2003. Paisaje y pisos geoecológicos en las áreas libres de hielo de la Antártida Marítima (Islas Shetland del Sur). Boletín de la Asociación de Geógrafos Españoles 35 $5-32$.

Serrano, E., López-Martínez, J., 2000. Rock glaciers in the South Shetland Islands, Western Antarctica. Geomorphology 35, 145-162.

Serrano, E., López-Martínez, J., Cuchí, J.A., Durán, J.J., Mink, S., Navas, A., 2008. In: Kane, D.L., Hinkel, K.M. (Eds.), Permafrost in the South Shetland Islands (Maritime Antarctica): spatial distribution pattern. Proceedings of 9th International Conference on Permafrost. vol. 2. University of Alaska Fairbanks, Alaska, USA, pp. 1621-1625.

Sharkhuu, N., Sharkhuu, A., 2012. Effects of climate warming and vegetation cover on permafrost of Mongolia. In: Werger, M.J.A., Staalduinen, M.A. (Eds.), Eurasian Steppes. Ecological Problems and Livelihoods in a Changing WorldPlant and Vegetation Volume 6. Springer, pp. 445-472.

Simms, A.R., Ivins, E.R., DeWitt, R., Kouremenos, P., Simkins, L.M., 2012. Timing of the most recent Neoglacial advance and retreat in the South Shetland Islands, Antarctic Peninsula: insights from raised beaches and Holocene uplift rates. Quat. Sci. Rev. 47, 41-55.

Smellie, J.L., Davies, R.E.S., Thomson, M.R.A., 1980. Geology of a Mesozoic intra-arc sequence on Byers Peninsula, Livingston Island, South Shetland Islands. British Antarctic Survey Bulletin 50, 55-76.

Smellie, J.L., Pankhurst, R.J., Thomson, M.R.A., Davies, R.E.S., 1984. The geology of the South Shetland Islands. VI: stratigraphy, geochemistry and evolution. Brit. Antarct. Surv., Sci. Repts 87, 1-85.

Toro, M., Camacho, A., Rochera, C., Rico, E., Bañón, M., Fernández-Valiente, E., Marco, E., Justel, A., Avendano, M.C., Arios, A.Y., Vincent, W.F., Quesada, A., 2007. Limnological characteristics of freshwater ecosystems of Byers. Polar Biol. 30 (5), 635-649.

Troll, C., 1968. Geoecology of the Mountainous Regions of the Tropical Americas. Ferd. Dümmers Verlag, Bonn. 
Troll, C., 1972. Geoecology of the High-Mountain Regions of Eurasia. Erdwissenschaftsliche Forschung der Akademie der Wissenschaften und der Literatur. Franz Steiner Verlag GMBH, Mainz.

Turner, J., Colwell, S.R., Marshall, G.J., Lachlan-Cope, T.A., Carleton, A.M., Jones, P.D., Lagun, V., Reid, P.A., lagovkina, S., 2005. Antarctic climate change during last 50 years. Int J. Climatol. 25, 279-294.

Vanhala, H., Lintinen, P., Ojala, A., 2009. Electrical resistivity study of permafrost on Ridnitsohkka Fell in Northwest Lapland, Finland. Geophysica 45, 103-118.

Vera, M.L., 2011. Colonization and demographic structure of Deschampsia Antarctica and Colobanthus quitensis along an altitudinal gradient on Livingston Island, South Shetland Islands, Antarctica. Polar Res. 30, 7146.

Vera, M.L., Fernández-Teruel, T., Quesada, A., 2013. Distribution and reproductive capacity of Deschampsia antarctica and Colobanthus quitensis on Byers Peninsula, Livingston Island, South Shetland Islands. Antarctica. Antarctic Sci. 25, 292-302.
Vieira, G., Mora, C., Pina, P., Schaefer, C., 2014. A proxy for snow cover and winter ground surface cooling: mapping Usnea sp. communities using high resolution remote sensing imagery (Maritime Antarctica). Geomorphology 225, 69-75.

Vieira, G., Bockheim, J., Guglielmin, M., Balks, M., Abramov, A.A., Boelhouwers, J., Cannone, N., Ganzert, L., Gilichinsky, D., Goryachkin, S., López-Martínez, J., Raffi, R., Ramos, M., Schaefer, C., Serrano, E., Simas, F., Sletten, R., Wagner, D., 2010. Thermal state of permafrost and active-layer monitoring in the Antarctic: advances during the international polar year 2007-2008. Permafr. Periglac. Process. 21, 182-197.

Yoon, H.I., Yoo, K.C., Park, B.K., Kim, Y., Khim, B.K., Kang, C.Y., 2004. The origin of massive diamicton in Marian and Potter Coves, King George Island, West Antarctica. Geosci. J. $8,1-10$.

Zarankin, A., Senatore, M.X., 2005. Archaeology in Antarctica: nineteenth-century capitalism expansion strategies. Int. J. Hist. Archaeol. 9 (1), 43-56. 